\title{
Researching globalisation
}

\author{
By Janet Dine
}

The author writes of the anger which led to Companies, International Trade and Human Rights (Cambridge University Press, 2005).

\section{Some scenes from today's world:}

Lee Kil-soo was found guilty of human trafficking. He owned the Daewoosa Samoa factory at Pago Pago, Samoa. Workers made clothes sold principally under Sears and JC Penney labels. The factory employed 251 immigrant workers from Vietnam and China in conditions described by John Ashcroft, US Attorney General as "nothing less than modern-day slavery". The workers paid \$200 a month for room and board, for which they received a bunk in a 36 bed dormitory and little food. Their pay was routinely withheld and after a strike to recover lost earnings managers switched off the electricity making the heat unbearable. In 2000 one of the seamstresses was dragged from her sewing machine and her eye was gouged out with a plastic pipe( D. Flickling "Misery of rag-trade slaves in America's Pacific outpost" in The Guardian, March 1, 2003)

The California court is being asked to grant compensation against Royal Dutch Shell because when the Movement for the Survival of the Ogoni People ["MOSOP"] was formed in Nigeria to oppose the coercive appropriation of Ogoni land without adequate compensation, and the severe damage to the local environment and economy that resulted from Royal Dutch Shell's operations in the Ogoni region in Nigeria, the movement was violently suppressed by the Government of Nigeria, acting at the request of Royal Dutch Shell. When Ken Saro-Wiwa was the leader of MOSOP and John Kpuinen was the deputy president of MOSOP's youth wing, Royal Dutch Shell, operating directly and through Shell Nigeria, recruited the Nigerian police and military to suppress MOSOP and to ensure that defendants' and Shell Nigeria's development activities could proceed "as usual." The corporate defendants provided logistical support, transportation, and weapons to Nigerian authorities to attack Ogoni villages and stifle opposition to Shell's oilexcavation activities. Ogoni residents were beaten, raped, shot, and/or killed during these raids.

In 1995, Ken Saro-Wiwa and John Kpuinen were hanged after being convicted of murder by a special tribunal. Royal Dutch Shell bribed witnesses to testify falsely at the trial, conspired with Nigerian authorities in meetings in Nigeria and the Netherlands to orchestrate the trial, and offered to free Ken Saro-Wiwa in return for an end to MOSOP's international protests against Shell. During the trial, members of Ken Saro-Wiwa's family, including his elderly mother, were beaten.

\begin{abstract}
"Japan has reduced its aluminium smelting capacity from 1.2 million tons to 149,000 tons and now imports 90\% of its aluminium. What this involves in human terms is suggested by a case study of the Philippine Associated Smelting and Refining Corporation (PASAR). PASAR operates a Japanesefinanced and constructed copper smelting plant in the Philippine province of Leyte to produce high grade copper cathodes for shipment to Japan. The plant occupies 400 acres of land expropriated by the Philippine Government from local residents at give-away prices. Gas and waste water emissions from the plant contain high concentrations of boron, arsenic, heavy metals, and sulfur compounds that have contaminated local water supplies, reduced fishing and rice yields, damaged the forests, and increased the occurrence of upper respiratory diseases among local residents. Local people whose homes, livelihoods and health have been sacrificed to PASAR are now largely dependant on the occasional part-time or contractual employment they are offered to do the plant's most dangerous and dirtiest jobs." (D.Korten, When Corporations Rule the World, Kumarian 1995)
\end{abstract}

The "energy giant" UNOCAL has settled a case brought by Burmese villagers who claim that the building of the Yadana gas pipeline had only been achieved by forced labour and by soldiers employing tactics of murder and rape to clear the way for the building of the pipeline. The villagers claimed that, at the request of UNOCAL the Burmese army "engaged in a pattern of systematic human rights abuses and environmental degradation ... [and] abuses such as killings, torture, rape and extortion by pipeline security forces have dramatically increased since the Yadana project was initiated.

While the villagers may get compensation, the company has still not admitted its wrongdoing, nor has a court made a final finding that the company was indeed responsible.

\section{THE TRIUMPH OF CAPITALISM?}

Using almost any statistics "we certainly know that the problem of world poverty is catastrophic" (T. Pogge "The First Millennium Development Goal" www.etikk.ne/ globaljustice). 
- Of 6133million human beings, in 2001 some 799million are undernourished (United Nations Development Programme Report 2003, p87);

- 50,000 humans daily die of poverty related causes. (WHO Report 2003, Geneva)

- 1,000 million lack access to safe drinking water

This means that "the global poverty death toll over the 15 years since the end of the Cold War was around 270 million, roughly the population of the US." (Pogge, Millenium Goal). And the figures go on and on;

- 34,000 children under 5 die daily from huger and preventable diseases (US Department of Agriculture )

- 1000 million lack access to safe drinking water (UNDP 2003)

What's the connection between these scenes? Corporations and their operation on the international stage.

"Imagine some visionary statesman, in 1830 say, posing the question of how the advanced states of Europe and North America can preserve and, if possible, expand their economic dominance over the rest of the world. . . Find the best solution to this task you can think of and then compare it to the world today. Could the West have done any better?" (T.

Pogge, World Poverty and Human Rights, Polity Press in association with Blackwell, Oxford 2002, p5)

And how has this happened? Well, everyone involved in the "globalisation" debate knows that multinational companies are part of the answer. Why is it that multinational companies are loathed, feared and worshipped worldwide? How have they become so powerful? And what is their link with world poverty? MNCs systematically drain resources from poor countries to rich ones and that is what they are legally designed to do ... How? Well, here's how ...

In The Corporation, Joel Bakan explains how companies act as "an externalising machine" legally obliged to concentrate exclusively on making money; "the corporation can neither recognise nor act upon moral reasons to refrain from harming others". ( Joel Balkan The Corporation, Constable, London, 2004). Why? The amoral nature of their design; they are legally obliged to maximise profits at the expense of any other consideration, whether environmental damage or worker welfare.

But there's more; the whole power structure of the international community is designed to serve the interests of TNCs. The World Trade Organisation, World Bank and International Monetary Fund are the three most powerful institutions on earth and multinational companies are their treasured darlings, cosseted and protected from any form of national and international control.

Let's look first at how companies operate on the international stage.

\section{COMPANIES DON'T EXIST!}

Companies are a legal fiction. A company is regarded as a legal person separate from its shareholders and managers for several practical reasons; it means it can continue to exist even if all its shareholders die or sell their shares, it means it can hold property in its own right and appear in front of a court in its own name. The shareholders can be regarded as separate persons and will normally have limited liability. That means that, once they have paid the price for their shares they are not obliged to contribute any more to the company even if the company has not enough money to pay all its creditors. As a result the only money available to pay the company's debts is the money owned by that company. If there isn't enough money the creditors don't get paid.

In order to understand the legal complexity which this legal fiction brings with it, it is necessary to start with an understanding of single companies. Companies are regarded as separate legal entities, owning their own property and with their own liability for contracts, crimes and other wrongs they may commit. The liability of their shareholders is limited to the amount paid for the ownership of their share. Companies played a vital role in first the industrial and subsequently the technological revolutions by limiting the risk faced by investors, enabling the raising of large sums of money from many sources in order to fund large projects (such as railways and canals) and undertake expensive research and development (for example into new medical treatments and drugs). The fact that shareholders knew with certainty the maximum amount they could lose enabled them to calculate what they could afford to invest.

The number of investors also meant that it was impossible for each of them to have a say in day to day decision making of the business, it became necessary to appoint dedicated managers. Of course, this was a fantastically useful structure when the great engineering works of the industrial age were being started. Building a railway was a risky and very expensive business and allowing a large number of people to contribute a small amount of money and guaranteeing that they could only lose their stake, no more ... and holding out the possibility that they might gain a fortune was a brilliant design. If limited liability companies had not been invented such enterprises would have been much more difficult as any contributors to the enterprise would have been partners who would have been obliged to pay the debts of the enterprise even if that meant using up the whole of their wealth, losing their house, taking their children out of school and facing destitution. But this design has gone wrong, rigging the risk so massively in favour of the shareholders has caused companies to run out of control and company design is still back in the pre-industrial age.

The growth of the so-called multinational and transnational corporations is possible because the legal 
systems of most countries regard one company holding shares in another in exactly the same way as if it were a human individual shareholder. Thus, the legal systems take no account of the reality of the accumulation of power represented by a large number of companies related by interlocking shareholdings. Many companies are organised in this "group" structure where control is exercised over a number of subsidiaries by a significant number of the shares being held by another, "parent" company. The easiest case is an hierarchy with $100 \%$ shareholding by a parent company but there are numerous other ways of creating effective control of one company over others by different share structures.

\section{MULTINATIONAL COMPANIES DON'T EXIST}

So, there's an even stronger reason to argue that multinational companies don't exist. This is because, as we have seen, companies are a legal fiction. That means that they are invented by the law in each country which also has the power (and usually exclusive power) to regulate it. . Multinational and transnational companies do not exist as an entity defined or recognised by law. They are made up of complex structures of individual companies with an enormous variety of interrelationships. Globalisation means that the world appears to be a smaller place; goods and people move freely across borders. But companies are legally tied to the country where they are formed; regulations made in other countries cannot have any impact. So-called multinational companies are a series of companies formed in different countries and tied together in various legal ways, either by holding shares in each other or by various legally binding agreements between them. This legal design is exploited by companies which export their dirty and dangerous business to poor countries where regulations are minimal and not enforced, enabling them to pay low wages and ignore the environmental effects of their operations. Such countries are often desperate for any foreign investment. Suppose damage is done to the health of employees. They will find it difficult or impossible to claim against the local operator as the legal system will either be structured to favour the company so as to attract the investor or the legal system may be corrupt or dysfunctional. They will find it impossible to claim against the foreign company which is the "parent" or head company because it is a separate company, structured according to the laws of a different jurisdiction and legally not responsible for the acts of other companies in the group, even if they are very closely tied together by owning many of the shares or by contractual arrangements. Only in very exceptional cases will the courts in rich countries make an exception and "lift the veil", that is, look to the reality of the situation which would indicate that the companies are closely tied together and that the parent company can issue instructions to its related company in the poor country.
Let's look at an example. In Adams $v$ Cape Industries (1990 BCLC) several hundred employees of the group headed by Cape Industries had been awarded damages for injuries received as a result of exposure to asbestos dust. Many of them are dying an unpleasant and lingering death. The injuries had been received in the course of their employment. The damages had been awarded in a Texan court but Cape Industries had no assets in Texas so the claimants could get no money there. They tried to enforce the claims in England where Cape had its head office and considerable assets. The English Court of Appeal held that the awards could not be enforced in England against Cape even though one of the defendants was a subsidiary of Cape's and the group had been restructured to avoid liability. The restructuring was blatant. The US subsidiary which had been responsible for marketing in America (North American Asbestos Corporation (NAAC) was put into liquidation and ceased to exist. Instead two new companies were formed, a company formed in Liechtenstein whose shares were held by a subsidiary of Cape and an Illinois company (Continental Productions Corporation) (CPC) whose shares were held by the expresident of NAAC. They were put in charge of the US marketing. Now there remained no legal link between Cape and CPC because Cape no longer held any shares.

However, the reality was that the ex-president who held all the shares remained loyal to Cape's interests and controlled CPC. In the case of the Illinois corporation a new legal link was introduced to add to the chain which connected Cape to its marketing operation. Both moves were clearly and admittedly intended to avoid liability to the outstanding claims for asbestosis injury which Cape knew were in the pipeline. Slade J said:

"Our law, for better or worse, recognises the creation of subsidiary companies, which, though in one sense the creation of their parent companies, will nevertheless under the general law fall to be treated as separate legal entities with all the rights and liabilities which would normally attach to separate legal entities... We do not accept as a matter of law that the court is entitled to lift the corporate veil as against a defendant company which is the member of a corporate group merely because the corporate structure has been used so as to ensure that the legal liability (if any) in respect of particular future activities of the group ... will fall on another member of the group rather than the defendant company. Whether or not this is desirable, the right to use a corporate structure in this way is inherent in our law."

And

"If a company chooses to arrange the affairs of its group in such a way that the business carried on in a particular foreign country is the business of the subsidiary and not its own, it is, in our judgment, entitled to do so. Neither in this class of case nor in any other class of case is it open to this court to disregard the principle of Salomon v Salomon [1897] AC 22 merely because it considers it just so to do." 
And such a legal outcome is commonplace throughout the world. This means that all the company's problems can be exported away from the nice, clean, rich world to poverty stricken areas where any sort of work, including scavenging from rubbish tips is welcome and no inconvenient checks on health and safety, environmental or labour standards can have any effect on the Head office company. True, in theory, the subsidiary company in the poor country could be answerable under that country's laws but apart from the possibility of corruption or dysfunction in the legal systems of those countries, two other difficulties arise; One is that the parent company can simply cause its creature in the poor country to disappear; under that legal system it can instruct it to liquidate, if necessary transferring any funds to the head office. The employees are left with a blank space, they have no company to sue; it's just disappeared. Further, often, any regulatory controls are bargained away before the company agrees to set up a business.

Korten quotes a Philippine Government advertisement (1995): “To attract companies like yours . . . we have felled mountains, razed jungles, filled swamps, moved rivers, relocated towns . . . all to make it easier for you and your business here."'(Korten, When Corporations Rule the World). Some countries are so desperate to attract "Foreign direct investment", that they will promise not to regulate their activities. Why? Well, many countries suffer from geographical disadvantages, lack of natural resources, the hangover of colonialism and debt, others may have too much wealth. Too much wealth? How can that be a problem? Well, it attracts gangsters; many people believe that the global economic order is not to blame for severe poverty and increasing global inequality; rather "poverty is substantially caused not by global, systemic factors, but - in the countries where it occurs - by their flawed national economic regimes and by their corrupt and incompetent elites, both of which impede national economic growth and a fairer distribution of the national product." (T. Pogge, World Poverty and Human Rights).

This comforting belief is accompanied by demands that the poor countries must first help themselves by giving themselves respectable political regimes. Since, until imposition of regime change in Iraq, it is not the responsibility of rich nations to impose regimes on others, nothing can be done. Aid, if given, would only be lost to corrupt elites. However these comfortable beliefs "are nevertheless ultimately unsatisfactory, because it portrays the corrupt social institutions and corrupt elites prevalent in the poor countries . . . as a fact that explains, but does not itself stand in need of explanation." The prevalence of bad regimes itself requires an explanation. By way of providing an explanation, Pogge focuses on the extraordinary double standards applied to a gang of thieves overpowering the guards at a warehouse and stealing the contents as opposed to a group overpowering an elected government. The latter (but not the former) become owners of the contents able to dispose of the natural resources of the country, which they will do by selling them to multinational companies, usually taking a large cut for themselves. They will also have available the possibility of borrowing huge sums of money from private banks or international institutions such as the International Monetary Fund. It will be the unfortunate citizens of the country who will be stuck with the debt repayments, even if they displace the gangsters with a democratic regime. Argentina should be a rich country but it owes $\$ 90$ billion to the International monetary fund, mostly debts incurred by its previous vicious dictatorships and over $50 \%$ of its population live in destitution as it struggles to pay off huge debts incurred by these previous repressive regimes.

Thus, as Pogge says:

"Indifferent to how governmental power is acquired, the international resource privilege provides powerful incentives toward coup attempts and civil wars in the resource-rich countries. Consider Nigeria, for instance, where oil exports of \$6-\$10 billion annually constitute roughly a quarter of GDP. Whoever takes power there, by whatever means, can count on this revenue stream to enrich himself and to cement his rule. This is quite a temptation for military officers, and during 28 of the past 32 years Nigeria has indeed been ruled by military strongmen who took power and ruled by force. Able to buy means of repression abroad and support from other officers at home, such rulers were not dependant on popular support and thus made few productive investments towards stimulating poverty eradication or even economic growth."

The failure to alter the prevalence of corruption under Olusegun Obasanjo ... "has provoked surprise. But it makes sense against the background of the international resource privilege: Nigeria's military officers know well that they can capture the oil revenues by overthrowing Obasanjo." So they must be kept sweet by corrupt payments.

An expose of the way in which the system works has been provided by Global Witness ( "Time for Transparency: Coming Clean on Oil, Mining and Gas Revenues", www.globalwitness.org, March 24, 2004). They report that in Congo Brazzaville, Angola and Equatorial Guinea huge sums of oil and extractive revenues have vanished from sight, paid as bribes by the companies to the local elites. This is despite a voluntary disclosure code launched by the UK Government in 2003. A UK Government spokesperson explained that it was for the governments of these countries to stamp out corruption.

\section{YOU ARE THE CEO: OR WHAT MAKES GOOD PEOPLE DO BAD THINGS}

OK, so what would you do? Your company is a public company, with a headquarters in London and operating throughout the world with various subsidiaries. Your scientific adviser tells you that in six months a new 
environmental Directive will come into force which will require significant investment to safeguard the health of your employees. This will halve the profits made by the company in Europe. No such regulations will apply in Indonesia and the wages bill will be 10 times lower if the products are manufactured there since trade unions are suppressed and the minimum wage is less than the amount needed to survive. The cost of waste disposal is minimal as any waste can be discharged into the local rivers. The transport costs will only offset this saving to a minimal degree and if employees suffer there is no chance of then gaining compensation in England (because of Adams $v$ Cape). Your duty is to maximise the profits to shareholders and your share options and bonuses depend on the company's continued prosperity.

You also have a subsidiary which is the subject of litigation. In South Africa, Genetic is a wholly owned subsidiary which is being sued by a group of employees who claim that their health has been damaged by working with dangerous chemicals. Genetic is also being prosecuted by the South African authorities for polluting the river next to the factory. The prosecution could lead to a fine of over $\$ 2$ million. Your lawyers advise you to remove all the assets of Genetic and put it into liquidation. Where does your duty lie?

\section{WHERE ARE THE SHAREHOLDERS?}

Who benefits? Well, we do. The clothes and electrical equipment we buy has been made cheaply at huge cost in human misery and environmental degradation. The profits of the multinational companies spiral upwards with many of us complicit either by directly owning shares or by investing in pension or insurance funds which themselves invest in shares of these monsters. But we can sit comfortably and blame the evil multinationals for their evil ways, secure in the knowledge that without changing their psychopathic structure, nothing will change and we can continue to benefit from their misdeeds.

\section{INVISIBLE CORPORATIONS}

Effectively, law performs a conjuring trick in order to disguise the power concentrations and opportunity for manipulation in corporate groups. Scott ( J Scott "Corporate Groups and Network Structure" in Corporate Control and Accountability (McCaherty, Picciotto and Scott eds, Clarendon, Oxford, 1993) traces this distorted perception back to classic economic analysis:

"Economic analysis was predicated on the role played by the individual entrepreneur in organising production. Classical economists assumed that 'entrepreneurs' headed firms which they personally owned; and they could see no obvious reason to modify this view when analysing the behaviour of the modern, large scale business corporation."

(Scott) Blumberg ( P. Blumberg "The American Law of Corporate Groups" in Corporate Control and Accountability
(McCaherty, Picciotto and Scott eds; Clarendon Press 1993) identifies two other reasons in the context of US law: the fact that it wasn't possible until 1888-93 for one corporation to become a shareholder in another corporation and that when the issue of the liability of parent corporations first came before the courts not only had the limited liability of shareholders been accepted for decades but that at the time.

"American law was experiencing the high tide of formalism, or conceptualism, as the only legitimate form of legal analysis.

Shareholders were not liable for the obligations of the corporations of which they were shareholders. A parent company was a shareholder. [Therefore], a parent corporation was not liable for the obligations of its subsidiary corporations of which it was a shareholder." (Blumberg)

So the courts determined that there was no difference between a solitary individual owning a few shares in a giant company and one company owning shares in another, even if it owned a majority of the shares and could consequently appoint the directors and manipulate the finances of the other company. Despite the "dramatic change in the underlying relationship" (Blumberg) which occurs when companies form themselves into groups, this analysis prevailed and is still evident today both in US and UK jurisprudence. What this does is create a legal pretence which completely ignores and disguises the cumulative power which a group of companies may exert over suppliers, consumers, employees and the political system. Suppliers will be frightened that if they are put on a "black list' they will have no destination for their produce, consumers may get less choice and may be subject to price fluctuations at the will of the group, employees will fear loss of a job as alternative possibilities shrink and politicians will be subject to the threat of increasing unpopularity if a group of companies threatens to take its operations elsewhere causing a collapse in local economies.

Economists sometimes describe companies as a series of individual contracts; between suppliers and the buyer (in the company), between employees and the person (in the company) who employs them, and so on. This vision also misrepresents the cumulative power of the company by reducing its operations to the individual transactions which make up the operation. It also carries the suggestion of equality, these individual transactions look as if real bargains are being struck, whereas, you as an employee, try telling Gap or Nike what terms of employment you would like. OK if you are Tiger Woods promoting Nike products, but not for the rest of us.

Thus, the reality of corporate power is rather different from the fragmented vision of the economists. Very few inhabitants of the planet are untouched by the activities of companies and some argue that they are taking over the world at the expense of the nation state and to the detriment of developing nations and the environment. "At the heart of the . . . capitalist system, the free market 
economy, lies company law".(B. Pettet, Company Law, Pearson Education, Edinburgh, 2001, p3.)

It is through the medium of companies that wealth is created. More than this, the way in which companies are regulated says a great deal about the values that each society and the global community gives preference to.

The concept of a company carrying on business in several countries is far from new. However this activity has increased enormously in recent years and current statistics contain a rather frightening message. According to the UN's World Investment Report 2001 the world has about 45,000 transnational firms controlling 280,000 foreign affiliates. Worldwide sales of the latter amounted to about $\$ 7$ trillion. The largest 100 companies own about $\$ 1.7$ trillion of foreign assets - a fifth of the estimated global total. Multinational companies account for 51 of the world's largest economic entities (the other 49 are nation states). (S. Anderson and J Cavanaugh, The Rise of Global Corporate Power (Institute for policy Studies, Washington DC, 1996).

The important characteristic of the multinational phenomenon is that management are being increasingly responsible for activities on an international basis. Their horizons are no longer limited by national or local considerations. A useful definition is that put forward by the Commission of Transnational Corporations in its draft code of conduct for Transnational Corporations. The emphasis is on "a system of decision making, permitting coherent policies and a common strategy through one or more decision-making centres "(United Nations Economic and Social Council Work on the Formulation of the United Nations Code of Conduct on Transnational Corporations- Outstanding Issues in the Draft Code of Conduct on Transnational Corporations (May 22, 1985). The whole decision-making structure has the world as its focus. This, coupled with the reason for the existence of companies which is often seen to be to make the maximum profit for shareholders creates a system which lays poorer countries open to exploitation.

Where all the component companies of a group are situated in one legal jurisdiction it is open to the laws of that country to treat the group as a single entity where the formal legal structure is being used for fraudulent purposes. This is often termed "lifting the corporate veil", and many jurisdictions (including the countries of the European Union) collect tax from groups of companies on this basis.

However, where companies use group structures but spread themselves across different legal jurisdictions many problems arise. Because many developing states are desperate for Foreign Direct Investment they will offer tax holidays and lax regulatory regimes in order to entice the powerful multinationals to invest. Take an example where a parent company is situated in a rich OECD country (as most of them are). It has control over a subsidiary in a developing country because of its shareholding in that subsidiary. The parent and its associated group have a turnover which is greater than that of the state where its subsidiary is located and has therefore been able to bargain for a very loose regulatory regime in the subsidiary's host state. The subsidiary is causing environmental degradation and imposing terrible working conditions on its labour force.

What legal results follow from this scenario?

The poor country is in breach of its duty to protect its citizens who are forced to work in poor conditions and endure the environmental damage. It will be reluctant to try and enforce higher standards if the parent company is likely to withdraw the subsidiary from the country. This is the "race to the bottom" in regulatory standards. Remember the parent can cause the subsidiary to vanish (liquidate), transfer all its funds to the parent or simply stop doing business.

In the poor country the parent company will be viewed as a separate entity from the subsidiary and, because it owes its existence to the laws of a foreign country (the rich state) it has no legal presence in the poor country state and can incur no liability even if the courts of the country were functioning fairly and effectively. In the extremely unlikely event that the legal system of the poor country 'lifts the veil' and finds the parent liable it will be difficult for those damaged to enforce judgment against a parent situated in a foreign country and funds may also be diverted elsewhere in the group and/or the company may liquidate.

Now attention should be turned to the legal results of this scenario in the home state of the parent (the rich country). The separate legal status of the parent company will be very likely to allow the parent corporation to escape from any liability for the actions of its subsidiary. The subsidiary has no legal presence in the rich country so cannot be subject to any liability there. No prizes for guessing the winners and losers in this international legal game.

In terms of the globalisation debate, the problems associated with multinational companies are compounded because they may not even be shareholders of the companies which they use to supply their component parts. Many companies are linked only by contracts of supply so that although they are effectively entirely dependant on retaining the goodwill of the central management of the multinational, they are legally not connected to them by structural ties. This problem is made worse when the suppliers contract out work to homeworkers whose conditions are impossible to monitor or inspect. There are a multitude (well over 400) Codes of Conduct which seek to impose control over the operation of multinational corporations but none of these have any legal remedies for breach. Monitoring the compliance of corporations with these Codes is extremely difficult, not least because much of the relevant information is under the control of the company itself. 
Let's look at one more example; the worst industrial disaster in history, a massive leak of toxic gas on the night of December 2-3, 1984. At the time of writing we are 20 years on and added to the approximately 25,000 killed (no-one knows the exact number as many families were simply wiped out)and 500,000 injured that night are added current day victims. The plant has never been cleaned up, children still play with the poisons that remain and pollution due to the plant is poisoning the water. Respiratory problems, persistent coughs, fevers, depression, deaths from cancer, deformations at births and anorexia remain significantly higher in this blighted city of Bhopal, India. Some 15,000 people are still chronically ill as a result of the tragedy and on-going pollution. Samples taken by Greenpeace from local water supplies showed a carbon tetrachloride level 682 times higher than the acceptable maximum, chloroform level 260 times higher and a trichloroethylene level 50 times higher. (D. Lapierre and J. Moro, Five Minutes past Midnight in Bhopal, Scribner, London, 2003, translated from the French by Kathryn Spink.)

The plant from which the devastation emanated was owned by Union Carbide India, a subsidiary of the mighty United States company Union Carbide, a company with 130 subsidiaries in 40 countries, 500 production sites and 12,000 employees at the time. Forty tons of methyl isocyanate exploded that night because the safety systems had been shut down to save the running costs and the alarms disconnected. Union Carbide was sued in the
United States for 15 billion dollars. The case was never decided. Instead Union Carbide offered 470 million dollars in compensation without admission of liability and the official line is that the accident was caused by sabotage, not negligence. Further, that the plant was designed and built by Indian engineers and thus not the responsibility of the US parent. Facts are still emerging to contradict this version of events but official figures show that about half a million survivors eventually received compensation in the region of $£ 1,000$ for death of relatives and about half of that for serious injury. Union Carbide no longer exists, taken over 1n 1999 by the Dow Chemical Group. Warren Anderson, Chairman of Union Carbide resides in New York and Miami in comfortable retirement despite an Indian and Interpol arrest warrant for 'culpable homicide' issued in 1992 and never served.

Do corporations rule the world? And how can their power be curbed?

- (The charity founded by the authors of Five Minutes past Midnight in Bhopal is "Action Aid for the Children of Lepers in Calcutta”, Coachman's Cottage, Horsham Road, South Holmwood, Dorking, Surrey, RH5 4LZ, cheques to Dominique Lapierre City of Joy Aid, England)

Professor Janet Dine

Director of the Centre for Commercial Law Studies at Queen Mary College, London 